\title{
Basic facts about immigration in Tenerife
}

Dirk Godenau and Daniel Buraschi

June, 2018

Migratory movements and the presence of immigrants in our societies are at the centre of political and media attention in Europe. In a context in which xenophobic parties have alarmingly increased their support base and where rumors and false or biased news are skewing the public debate on migration, it is particularly urgent and important that civil society, institutions and the media have substantiated and verifiable information. Promoting and disseminating scientific knowledge on migratory phenomena is one of the main purposes of the Tenerife Immigration Observatory.

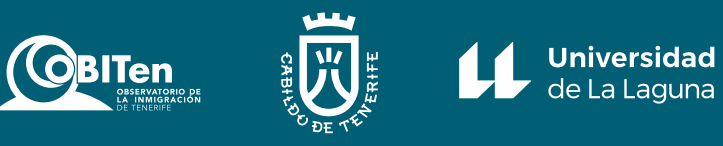




\section{How many are there?}

The immigrant population can be defined from the available statistics by using different criteria: nationality (foreigners vs. nationals), place of birth (abroad vs. national), or cross-border mobility (flow of people entering the country). The first two are measured for the resident population through the Population Register and the Population Censuses. In contrast, the measurement of migratory flows relies on changes in population registers or records of border crossings, whether regular or irregular. Beyond the statistical criteria, it should be noted that in the everyday life of the immigrant population, other factors, such as the phenotype (physical features), accents, clothing, customs, etc., also play a relevant role in identifying someone as "being an outsider", regardless of their place of origin or nationality.

In early 2017 , the population of Tenerife was 895,000 (Table 1), of which $177,000,19.8 \%$, had been born abroad, and 104,000, $11.6 \%$, were foreign nationals. The difference, of almost 74,000 people, is due mainly to the nationalisation of immigrants during their time in Spain and the immigration of people of Spanish nationality born abroad, these two phenomena occurring more frequently among people of American origin. This is reflected by the fact that the population born in American countries represents $10 \%$ of the population of Tenerife, but only $3 \%$ when it is limited to the corresponding nationalities.

Residents of Tenerife

Table 1 by place of birth, nationality and origin in 2017 and change with respect to 2000 .

Source

ISTAC. Population Register, on January 1 of the year.

\begin{tabular}{|c|c|c|c|c|c|c|c|}
\hline \multirow[b]{2}{*}{ Origin } & \multicolumn{3}{|c|}{ By place of birth } & \multicolumn{3}{|c|}{ By nationality } & \multirow{2}{*}{$\begin{array}{l}\text { Native/ } \\
\text { foreigner } \\
\text { ratio (\%) }\end{array}$} \\
\hline & Population & $\%$ & $\begin{array}{l}\text { Chg (\%) } \\
2000-17\end{array}$ & Population & $\%$ & $\begin{array}{l}\text { Chg (\%) } \\
2000-17\end{array}$ & \\
\hline Total & 894.636 & 100,0 & 26,1 & 894.636 & 100,0 & 26,1 & \\
\hline Foreigner & 177.456 & 19,8 & 233,0 & 103.703 & 11,6 & 231,7 & 171 \\
\hline $\begin{array}{l}\text { Rest of } \\
\text { EU-28 }\end{array}$ & 64.075 & 7,2 & 163,7 & 59.635 & 6,7 & 192,9 & 107 \\
\hline $\begin{array}{l}\text { Resto of } \\
\text { Europe }\end{array}$ & 6.173 & 0,7 & 450,7 & 5.243 & 0,6 & 602,8 & 118 \\
\hline Africa & 10.104 & 1,1 & 261,8 & 6.808 & 0,8 & 388,4 & 148 \\
\hline America & 87.999 & 9,8 & 294,7 & 25.681 & 2,9 & 280,3 & 343 \\
\hline Asia & 8.972 & 1,0 & 233,3 & 6.287 & 0,7 & 216,7 & 143 \\
\hline Oceania & 133 & 0,0 & 38,5 & 49 & 0,0 & 69,0 & 271 \\
\hline
\end{tabular}

\section{Where are they?}

In early 2017, Tenerife was home to $42 \%$ of the population living in the Canary Islands. It accounts for $45 \%$ of the region's foreign population and $47 \%$ of the population of born abroad. If we look at the trend in the immigrant population in the different islands (Graph 1), we can see that Tenerife shares with all the others a strong growth in this population during the economic boom between 2000 and 2007, followed by stagnation during the subsequent crisis. The percentage of the population born abroad in Tenerife 
is clearly lower than that recorded in Fuerteventura and Lanzarote, but also substantially higher than in Gran Canaria.

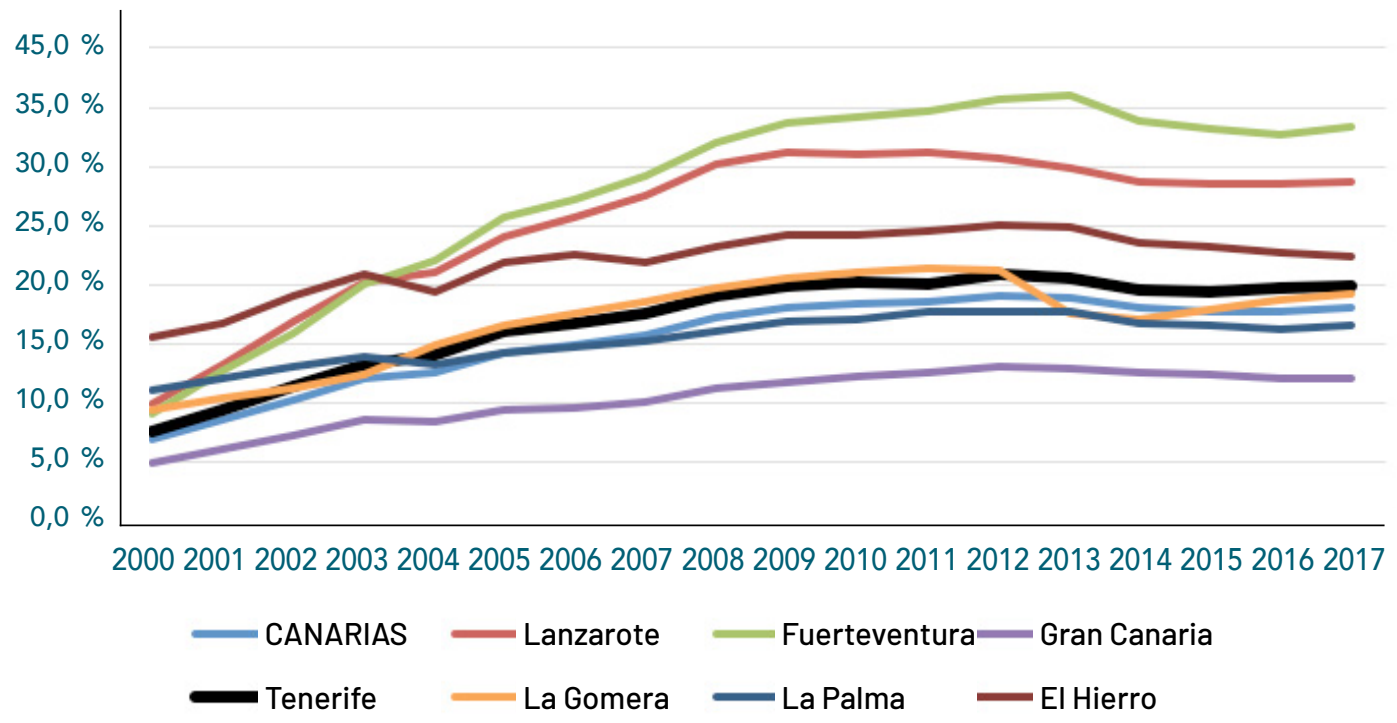

The territorial distribution of the immigrant population in Tenerife (Map 1) reflects the importance of economic and residential specialisation in some areas. It is in the tourist municipalities (Adeje, Arona, Santiago del Teide, Granadilla de Abona, Guía de Isora, San Miguel de Abona, Puerto de la Cruz) where the percentage of the population born elsewhere is higher. In contrast, in the more rural municipalities, these percentages are frequently below $10 \%$. Due to the different sizes and population percentages of the municipalities in Tenerife as a whole, the territorial distribution of the absolute number of foreign-born people follows a relatively concentrated pattern, with $70 \%$ of this population living in only 5 of Tenerife's 31 municipalities: Santa Cruz de Tenerife, San Cristobal de La Laguna, Arona, Adeje and Granadilla de Abona.

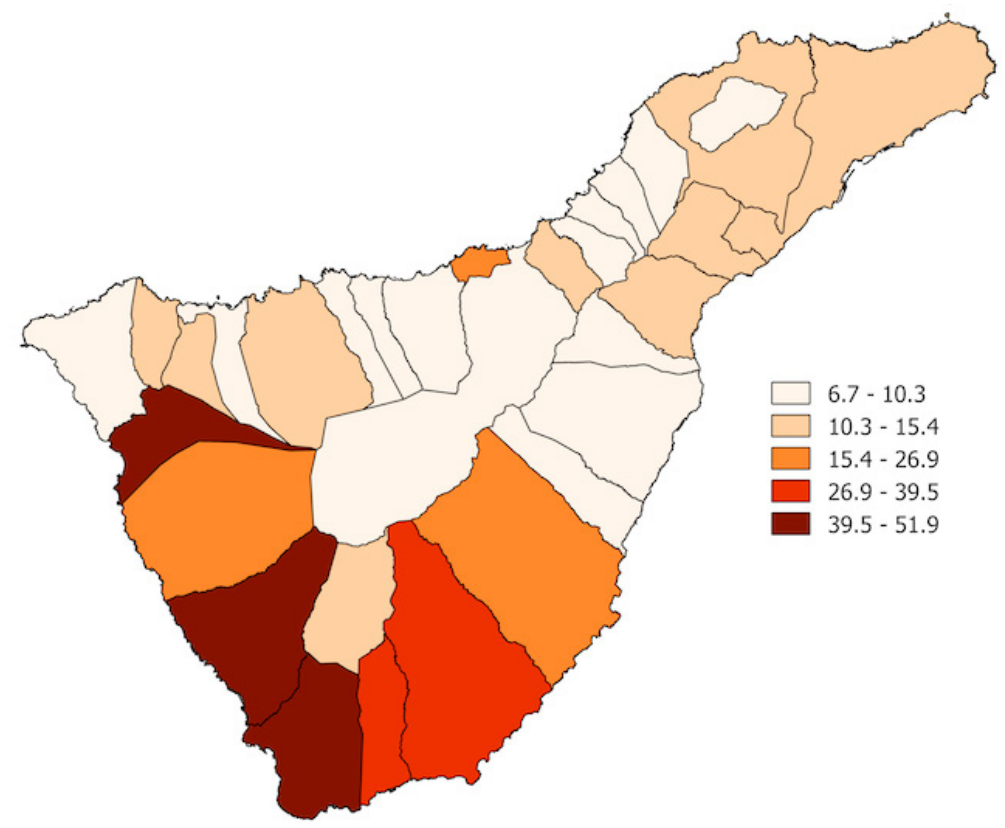

\section{Graph 1}

Trend in the percentage of the population born abroad by island between 1997 and 2017.

\section{Source}

ISTAC. Population Register, on January 1 of the year.

\section{Map 1}

Municipalities of Tenerife and the percentage of the population born abroad as of January 1 , 2017

\section{Source}

ISTAC. Population Register. 


\section{Where are they from?}

The population of Tenerife is made up of people from a wide range of origins and nationalities. The population born abroad comes from 170 different countries, with the most frequent places of birth (Table 2) being American countries (Venezuela, Cuba, Argentina, Colombia) and European countries (Italy, United Kingdom, Germany). The top African country, Morocco, ranks tenth in the list of countries of origin. The historical migratory links between the Canary Islands and Cuba, and later Venezuela, are manifested in the large percentage of people born in these countries who have Spanish nationality. In turn, it is the populations of Venezuela and Italy that have experienced strong growth in recent times.

Table 2

Top 10 countries and areas of origin or nationality of the resident immigrant population of Tenerife

in 2017.

Source

ISTAC. Population Register, on January 1 of the year

\begin{tabular}{c|l|c|c|l|c|c}
\hline \multirow{2}{*}{ Range } & \multicolumn{3}{|c|}{ Population born abroad } & \multicolumn{2}{c}{ Population of foreign nationality } \\
\cline { 2 - 7 } & Country & Population & $\begin{array}{l}\text { Chg (\%) } \\
\mathbf{2 0 0 0 - 1 7}\end{array}$ & Country & Population & $\begin{array}{l}\text { Chg (\%) } \\
\text { 2000-17 }\end{array}$ \\
\hline $1^{\circ}$ & Venezuela & 38.223 & 163,2 & Italy & 17.311 & 814,0 \\
\hline $2^{\circ}$ & Italy & 17.540 & 738,8 & United Kingdom & 11.793 & 74,7 \\
\hline $3^{\circ}$ & Cuba & 16.637 & 490,6 & Germany & 8.639 & 30,8 \\
\hline $4^{\circ}$ & United Kingdom & 12.826 & 66,0 & Venezuela & 7.676 & 166,0 \\
\hline $5^{\circ}$ & Germany & 9.758 & 24,5 & $\begin{array}{l}\text { 2004 EU } \\
\text { expansion }\end{array}$ & 6.130 & $2.648,9$ \\
\hline $6^{\circ}$ & Argentina & 8.001 & 392,1 & Cuba & 4.383 & 229,1 \\
\hline $7^{\circ}$ & $\begin{array}{l}\text { Other American } \\
\text { countries }\end{array}$ & 7.796 & 425,0 & $\begin{array}{l}\text { Other European } \\
\text { countries }\end{array}$ & 4.380 & $1.215,3$ \\
\hline $8^{\circ}$ & Colombia & 7.775 & $1.406,8$ & Romania & 3.566 & $4.994,3$ \\
\hline $9^{\circ}$ & $\begin{array}{l}2004 \text { EU } \\
\text { expansion }\end{array}$ & 6.240 & $2.202,6$ & Argentina & 3.547 & 358,3 \\
\hline $10^{\circ}$ & Morocco & 5.428 & 219,9 & $\begin{array}{l}\text { Other American } \\
\text { countries }\end{array}$ & 3.418 & 312,8 \\
\hline
\end{tabular}

\section{What profile do they have?}

The structure of Tenerife's immigrant population by age and sex is not substantially different from that of the Spanish population that resides on the island (Graph 2); in both cases, the percentage of middle-aged individuals is high. The differences lie in the somewhat younger age of the foreign population, as well as in the lower presence of minors.

However, this general situation results from a superposition of age and sex structures that are clearly differentiated between the different origins of the immigrant population. Due to the influx of many of the immigrants from non-European countries for labor reasons during the financial boom, this population reached the Canary Islands at relatively young ages. In contrast, many of the European immigrants are elderly people who come to Tenerife for residential reasons, and not to participate in the labor market. 

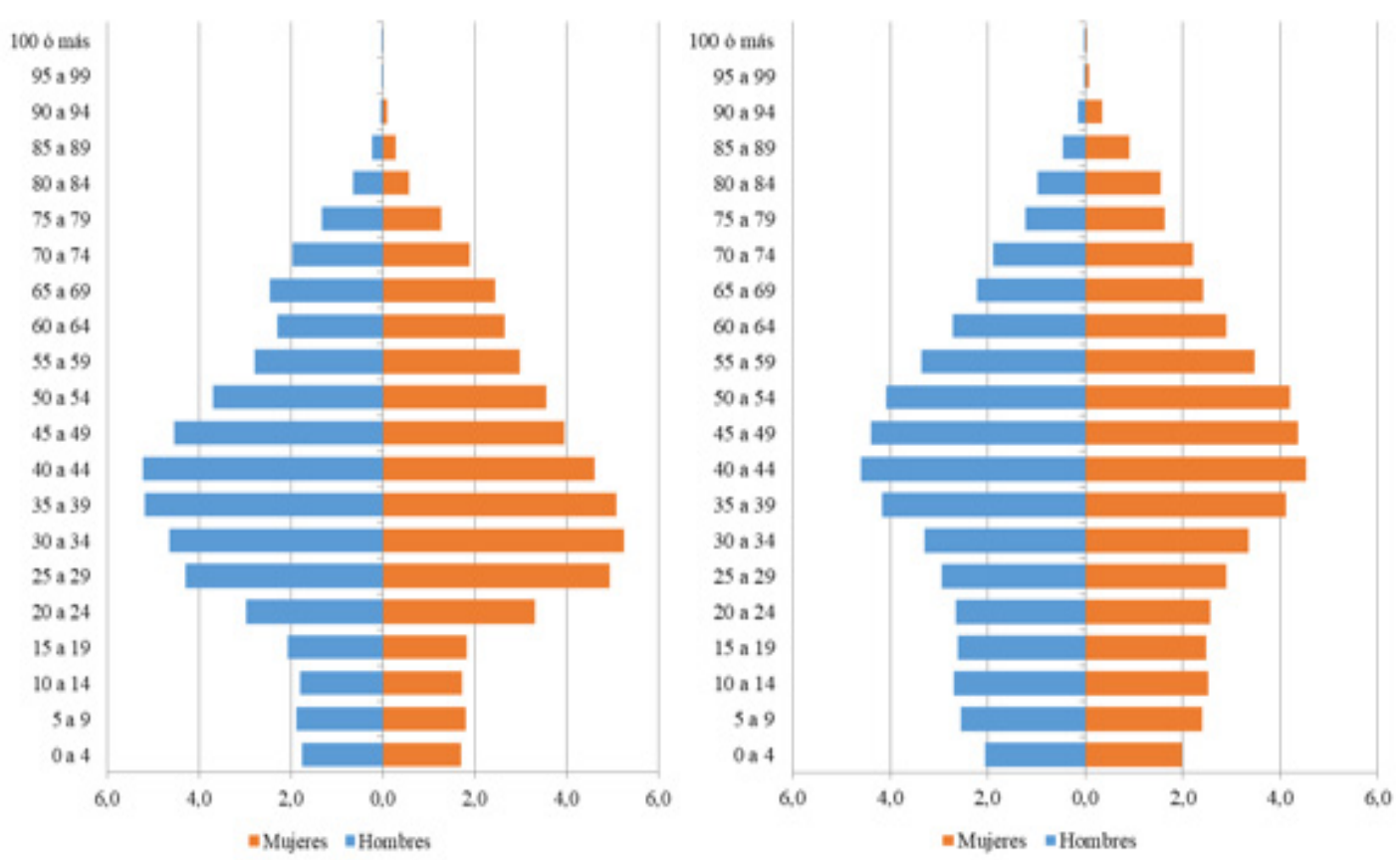

Graph 2

Population of Tenerife by age and sex on January $1,2017 \%$.

(foreign population in left panel, Spanish population in right panel).

\section{Source}

ISTAC. Population Register.

\section{How did they arrive?}

Moving now from the characteristics of the immigrant population to the migratory flows, that is, the people who enter and leave the island of Tenerife, the additions to (immigrations) and deletions from (emigrations) the Population Register provide an estimate of foreign migration balances (Graph 3).

Three different stages can be identified from 2002 to 2016. The first, through 2007 and during a period of economic growth, has a high migratory balance (net immigration); the second, from 2008 to 2015, resulting from the financial crisis, exhibits a sharp reduction in this balance to values that were even moderately negative in 2015; and the third stage, which began in 2016, reflects the consequences of the economic recovery through higher levels of immigration and a reduction in emigration (Domínguez and Díaz, included in Godenau and Buraschi, 2017b).

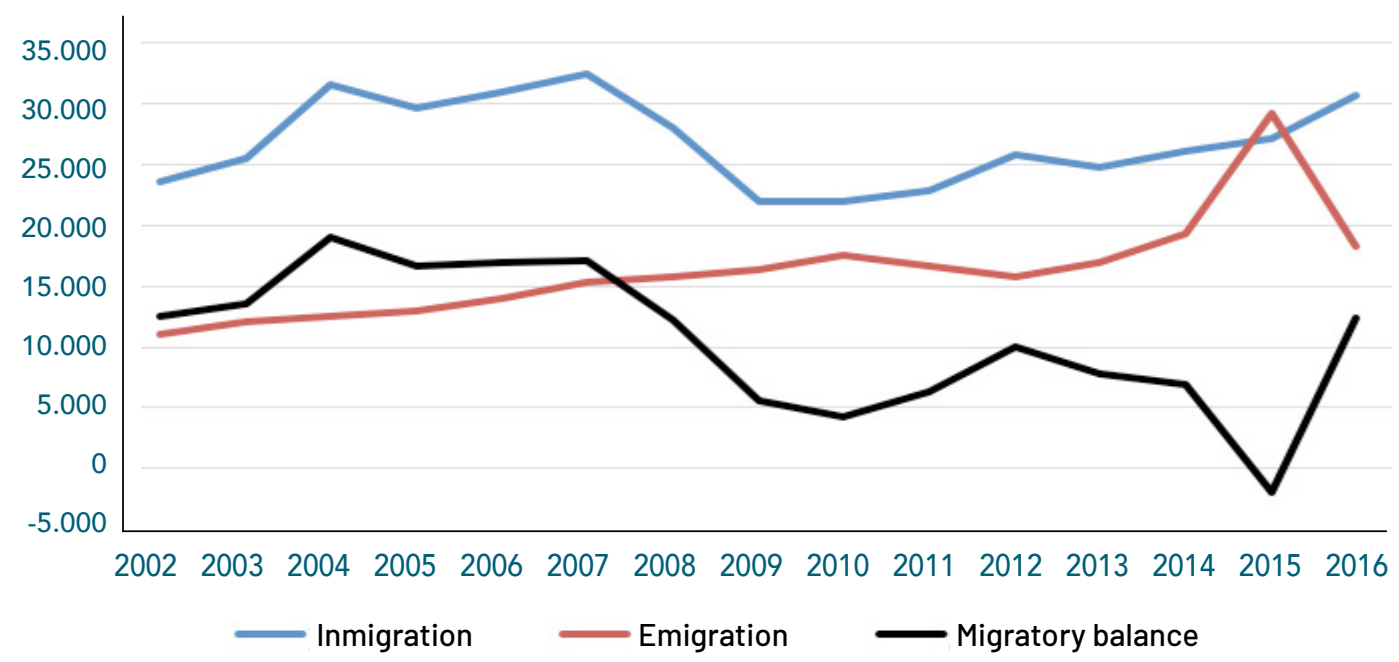

\section{Graph 3}

Trend in migration flows in Tenerife between 2002 and 2016.

(includes other islands, rest of Spain and abroad for both immigration and emigration).

\section{Source}

ISTAC. Statistics Residential Changes. 
Migratory flows can be classified by the government as regular or irregular. In the case of irregular migrations, it is useful to differentiate between irregular border crossings (for example, maritime arrivals in small boats) and overstaying visas. People who cross the border irregularly do not necessarily stay in the place of arrival, since they may move on to other territories, or, if intercepted, they may be diverted to other places by the authorities. In contrast, someone may enter a country legally (for example, as a tourist at an airport), and later lapse into an "unexpected" situation by lacking the mandatory residence permits.

The Canary Islands, as part of the Atlantic route of African emigration to Europe, is the place of arrival for people who set sail from the western coast of the neighboring continent in an effort to enter the European Union. From 2002 to 2008, these arrivals were much higher than in previous and subsequent dates (Graph 4), reaching a peak in 2006 during the so-called "cayuco crisis". This flow is now at lower levels, and the reactivation of the Atlantic route will depend on events on the eastern and western Mediterranean routes, which are relatively more permeable now. In 2017, 418 people arrived from the coasts of Africa on board 16 vessels. This is a very small number compared to 2006, which saw 31,678 people arrive. Of those arriving via this route in $2017,87.7 \%$ were adult men, $8.7 \%$ were minors and $3.5 \%$ were adult women. Most of the boats leave from Morocco or Western Sahara, but some also set sail from Senegal and Gambia (CEAR, 2017). Preliminary data for 2018 indicate a budding resurgence of this influx.

Graph 4

Detainees arriving at unauthorised entry points of the Canary

Islands on board vessels between 1994 and 2017.

Source

Ministry of the Interior and specialised press

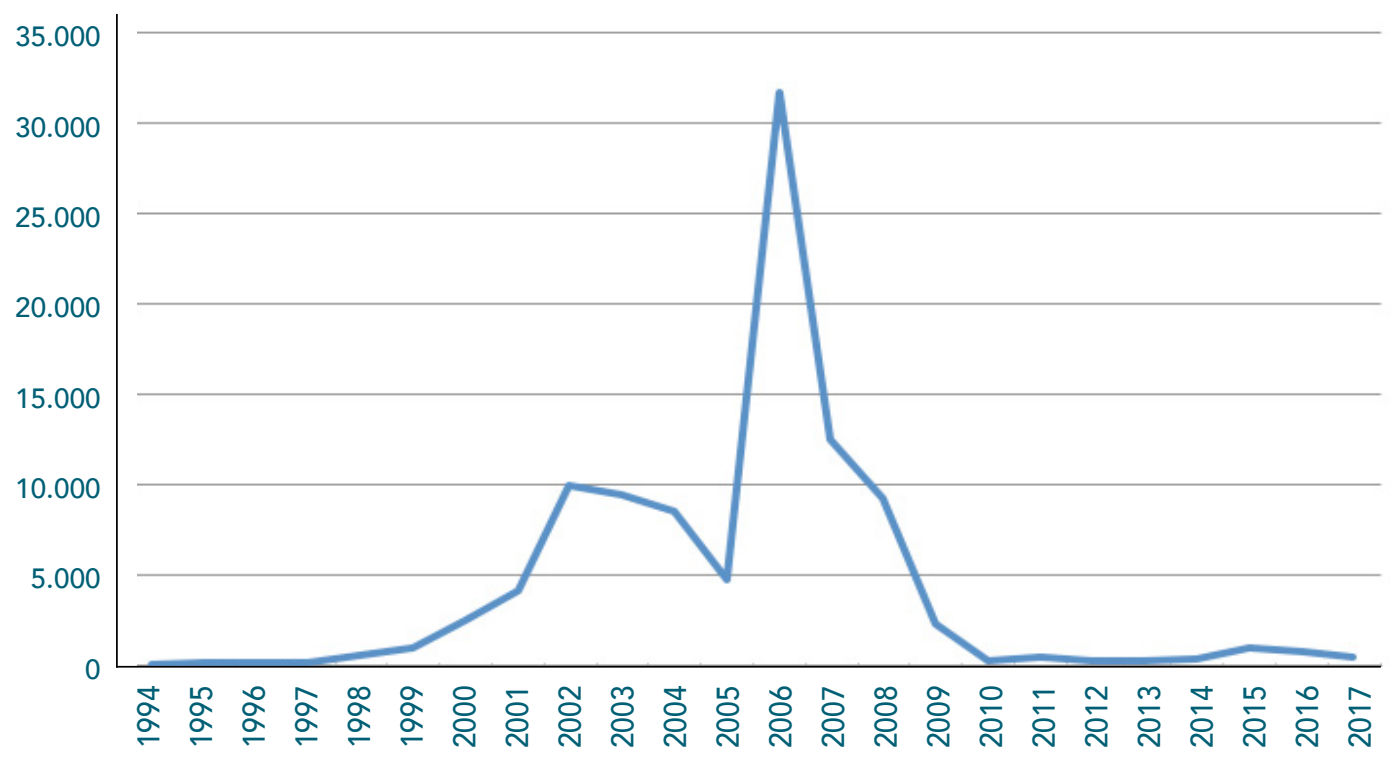

The low level of irregular maritime immigration to the Canary Islands implies, among other aspects, a lower rate of asylum claims in the Canary Islands. However, the presence of refugees on the archipelago, and the services rendered to them, is not limited to those who reach port on the islands in search of refuge, since they may also be transferred there from other regions. In 2017, 820 asylum requests were registered in the Canary Islands, most of them involving individuals who had traveled from Venezuela, Western Sahara and Ukraine. 


\section{What is their status?}

Immigrants who live in Tenerife are not only diverse in terms of their origins, but of many other aspects as well, such as their financial and social status in Tenerife society. In this sense, we should avoid the stereotypes that aim to reduce this diversity to simplifications centered at both extremes of the financial scale, namely, poverty and opulence.

Given this caveat, it seems appropriate to pay special attention to the difficulties experienced by a not insignificant part of the immigrant population. According to a study carried out for the Permanent Immigration Observatory in Spain on the different aspects of immigrant integration in Spanish regions (Godenau et al., 2017), many people living in the archipelago, whether immigrants or not, experience low wages, high unemployment rates and job insecurity. Of the Spanish regions, the Canary Islands has the smallest differences between foreigners and nationals, but one factor in this apparently successful integration is the unfavorable situation of the nationals (downward convergence). The labor disadvantages of the immigrant population are particularly evident in the problem of over-qualification, which indicates that some migrants are unable to put their training to use in the local labor market. The crisis has aggravated these problems (Godenau and Buraschi, 2017a).

This employment situation is the main factor that part of the immigrant population must face in order to earn the income they need for the material welfare of their families. The corresponding inequality and poverty indicators (Padrón Marrero, included in Godenau and Buraschi, 2017b) show that the immigrant population tends to have lower incomes than people born in the Canary Islands. The situation involving the indicators of social relations and citizenship is much more favorable, since the passage of time has yielded substantial improvements in terms of residential status and linguistic skills.

We must not forget that immigrants do not represent a homogeneous group: their living conditions in the Canary Islands vary greatly depending on the countries of origin, differences that are especially related to their employment status, household income, family structure and number of years living in Spain. The group that has suffered most from the effects of the economic crisis are people of African origin. According to the survey carried out by OBITen (Godenau and Buraschi, 2017a), 52.6\% of African immigrants had to reduce their food expenses due to the crisis, compared to $11.0 \%$ of immigrants from the European Union. As concerns the family structure, migrants living in single-person households and single-parent households (an adult with dependent children) have more problems making ends meet. 


\section{What will happen?}

The outlook for immigration trends in Tenerife is fundamentally conditioned by the economic situation. Once the economic crisis is over and job recovery begins, it is likely that emigration will continue to decrease and that immigration will resume. In fact, the regional population experienced a 1.03\% increase between 2017 and 2018, totaling around 20,000 new inhabitants, due primarily to a positive external migratory balance. This percent increase at the regional scale was only surpassed by the Balearic Islands and the region of Madrid. In the context of an aging European population, this will contribute to the renewal and diversification of the populations of Tenerife and the Canary Islands, a demographic vitality that is a key element to the future economic and social success.

\section{For more information:}

CEAR (2017), Refugiados y migrantes en España: Los muros invisibles tras la frontera sur, Madrid, Comisión Española de Ayuda al Refugiado. [available at https://www.cear.es]

Godenau, D. and Buraschi, D. (2017a), Movilidad y condiciones de vida de los inmigrantes durante la crisis económica en Tenerife, Cabildo de Tenerife, Área de Empleo, Comercio, Industria y Desarrollo Socioeconómico, Santa Cruz de Tenerife. [available at www.obiten.net]

Godenau and Buraschi (eds.) (2017b), Migraciones, desigualdad e integración en tiempos de crisis. Cabildo Insular de Tenerife, Área de Empleo, Comercio, Industria y Desarrollo Socioeconómico, Santa Cruz de Tenerife. [available at www.obiten.net]

Godenau, D., Rinken, S., Martínez de Lizarrondo Artola, A., Moreno Márquez, G. (2017), La integración de los inmigrantes en España: fases, patrones y dinámicas regionales durante el periodo 2007-2015, Ministerio de Empleo y Seguridad Social, Madrid. [available at http:// extranjeros.empleo.gob.es]

\section{How to cite this document:}

Godenau, D. \& Buraschi, D. (2018). Basic facts about immigration in Tenerife. OBITen Factsheet 1-2018. Retrieved from www. obiten.net

The Tenerife Immigration Observatory is a joint initiative of the Tenerife Council and the University of La Laguna that is intended to provide a permanent and dynamic structure to advance our scientific knowledge of migratory movements. The OBITen carries out its activity by gathering, producing and disseminating knowledge to facilitate qualified opinions and promote the making of decisions that help to better manage migratory phenomena and their implications.

http://www.obiten.net 